\title{
The Integration of Information Literacy Assignments within the Management Coursework as a Strategy for Development of Students' Independent Learning and Lifelong Learning Skills
}

\author{
Alina M. Zapalska, Michael McCarty, Kim Young-McLear, Nick Zieser, Tyler Kelley, Michael \\ Glinski \\ Coast Guard Academy U.S.
}

\begin{abstract}
This paper demonstrates how information literacy can be taught with coursework assignments using an example of the Management major at the U.S. Coast Guard Academy. Students are expected to explore, select, and evaluate information acquired from printed, electronic, academic, and popular sources to complete their information literacy tasks to complete assignments. When students finish their assignments, they are expected to master knowledge and develop their ability to complete their information literacy tasks. The integration of information literacy assignments within the management coursework illustrates an approach to improving students' capabilities to evaluate and apply newly acquired information. This paper also discusses an assessment instrument that can be used to evaluate the development of information literacy skills throughout four years of undergraduate study.
\end{abstract}

\section{Introduction}

As the sources of information continue to grow and information becomes increasingly available through a variety of resources and modes, academic programs have a responsibility to ensure that information literacy (IL) continues to be an important aspect of undergraduate education. Becoming information literate does not only make students thriving during their undergraduate studies, but it also prepares them for their professional careers and lifelong learning [27], [7]. IL skills highlight locating, reading, analyzing, selecting, evaluating, and using information to develop new knowledge [1], [5]. They are defined as a set of abilities that enable students and researchers to find, evaluate, and use ethically and legally acquired information [2]. IL skills development must be gradual and continuous while problem solving, critical thinking, analytical research, writing, presentation, and communication competences are proficiently mastered [9], [29].
Pedagogical research has demonstrated the importance of the IL education and its impact on the quality of assignments and undergraduate research projects and lifelong learning skills [16]. IL instruction is most successful when it is associated with a hand-on, case-based and problem-based learning with the use of assignments or written essays, or research projects within a course as opposed to a stand-alone subject delivered by library staff [9], [10], [17]. Studies promote the integration of development of IL skills across curricula and the use of case studies and authentic situations across study assignments, research papers, projects, and presentations [26]. Advocates of IL argue that specifically customized IL programs at any college level benefit students by allowing them to master IL skills from a basic level to a level of IL confidence, fluency, and proficiency [4], [11].

This paper presents the IL strategy employed by the Management Department at the U.S. Coast Guard Academy (CGA). Originally, the growth of IL curricula at the CGA was delivered by the library faculty, but since the early expansion of the program there have been several modifications to the curriculum and the faculty teaching IL across various Management major courses. The attainment of the IL educational outcomes at the CGA is based on Informational Literacy Competency Standards for Higher Education [4] outcomes and has been adopted for development and assessment in all courses in a specific sequence from freshman year to senior year. This paper delivers examples of IL assignments where students learn how to find, organize, and evaluate, and select the immense range of information that is available across different IL resources. The authors start with an overview of theoretical and applied research and discuss relevant IL issues and concepts. The focus is to present the process of designing and implementing an IL process in an undergraduate Management program with the use of hands-on learning that has been drawn from the field of education as well as from library and information science experience. 
In this paper, the authors conclude that the development and an assessment of IL at the CGA has been successfully implemented based on: (1) Determine the Extent of Information Needed, (2) Access the Needed Information; (3) Evaluate Information and Sources Critically; (4) Use nformation Effectively to Accomplish a Specific Purpose; and (5) Obtain and Use Information Ethically and Legally (Source: Informational Literacy Competency Standards for Higher Education [4]. The assessment process adopted is informal, takes place at the level of an individual course, and is performed separately for each individual assignment or project. Students are provided with feedback which indicates on what elements and on which IL level they failed, were satisfactory, or established proficiency.

\section{Information Literacy Background}

IL has been accepted as the most important learning outcome of higher education and a lifelong learning skill [18]. As information is becoming easily accessible everywhere, students must be educated on IL and hence learn how to locate, obtain, assess, and analyze information from numerous academic and popular sources. The United States has been regarded as leader in developing and implementing IL standards and academic programs [20]. Academic libraries have been delivering basic library instruction since 1876 but the concept of IL originated in 1914 [13]. The 1970s brought an enormous interest in educating students on library research and stressed the importance of IL as the most critical student learning outcome [25].

The IL instruction in the 1980s continued to be based on information retrieval from traditional library catalogues but it started emphasizing the value of IL instruction on student academic success [22]. In the 1990s, IL instruction gradually moved beyond the traditional library instruction to an information-based and resource-centered teaching approach within some specifically selected courses throughout four years of undergraduate education [28]. Since that time, the IL definition and its use, application, and assessment have been transformed to bring students' research into undergraduate classroom across curriculum as a tool for development of a lifelong learning skill that is based on the ability to acquire, evaluate, use, maintain, interpret, and communicate acquired information [18].

Over the years, undergraduate programs across all majors have initiated and enhanced the IL strategies and have recognized that academic faculty, librarians, and administrative staff must work together to address and promote IL teaching and learning at their institutions [23]. In order to meet those challenges, the ongoing development of non-traditional learning with the use of new technologies and increasing resources of information that can be used for learning and research must be done outside the library collections and instruction [19]. At present, academic faculty are expected to identify and develop IL fundamentals in their courses. Instead of creating new courses, the current curriculum with the existing IL instruction can be used for creating a more structured IL initiative [31]. As a result, a librarian-faculty partnership has been created to tailor IL instruction more effectively to course projects and assignments and to make significant contributions to the curriculum [12].

Today's IL education creates a classroom where experiential, self-directed, and independent learning engages undergraduate students in finding, selecting, and using specific information to analyze and solve problems, complete assignments, write reports or conduct undergraduate research projects [6], [32]. Through those numerous approaches to mastering IL skills, students not only develop knowledge, but they also practice communication, leadership, critical thinking [21], [32] and problem-solving skills [10]. These specially designed and employed learning strategies are critical as they enable students to develop the skills to ask questions, frame problems, conduct research [17] and find solutions while becoming active learners and are required to acquire information through numerous library and the Internet resources [14], [24].

This paper contributes to the existing literature by demonstrating examples of how IL can be taught in an undergraduate program with the use of coursework assignments. The assignments illustrate step-by-step instruction and requirements for students to find, select, assess, and apply the information retrieved from numerous library and internet resources. After completing their reports or assignments, students not only gain knowledge, but they also master IL skills. The integration of IL within the coursework illustrates how business undergraduate programs can enable students to generate new knowledge by advancing their IL skills while finding, selecting, evaluating, and applying acquired information within a challenging educational process.

\section{Il In the Management Major at The USCGA}

Developing lifelong learners is essential to the mission of the CGA Management Department. The Management faculty ensures that Management majors acquire the intellectual capabilities of reasoning and critical thinking that provide the foundation for continued growth throughout their Coast Guard careers. The IL educational process must be produced and delivered beyond the traditional classroom and 
should provide practice of IL skills with independent investigation as students focus their work on specific research projects, assignments, and reports.

\subsection{Model for Developing the IL Skills}

It is a relatively easy task to teach $\mathrm{IL}$, however it is more challenging to teach IL effectively. A list of standards and competencies is necessary so that the desired skills and knowledge can be specified and then taught with an appropriate strategy. Appropriate and effective pedagogical approaches with planning and designing active IL education and evaluation have been a major aspect of IL education at the CGA. The CGA faculty recognizes through the Academy's mission that $\mathrm{IL}$ is an independent and lifelong learning skill that is critical to the success of the CGA cadets and subsequently the Coast Guard as an organization. IL skills secure students with the critical skills necessary to become independent and lifelong learners. Figure 1 illustrates the relationship between a concept of IL in relation to students' independent learning and lifelong learning skills as suggested by the CGA IL educational program. The CGA is expecting that all graduating CGA students understand and become familiar with the qualities of the Information Age. The CGA students will develop and master strong analytical, critical thinking, problem-solving and research skills during four years of undergraduate study at the CGA in order to become competent and skilled public service employees who will most effectively contribute to completing the Coast Guard missions.

The Association of College and Research Libraries [4] has developed a definition based on the abilities of an information literate student that were published as Information Literacy Competency Standards for Higher Education in 2000.

This definition that has been by accepted and used by the Management Department faculty at the CGA defines an information literate person as an individual who is able to: (1) determine the extent of information needed; (2) access the needed information effectively and efficiently; (3) evaluate information and its sources critically; (4) incorporate selected information into one's knowledge; (5) use information effectively to accomplish a specific purpose; (6) understand the economic, legal, and social issues surrounding the use of information; and (7) access and use information ethically and legally (Association of College and Research Libraries, 2000).

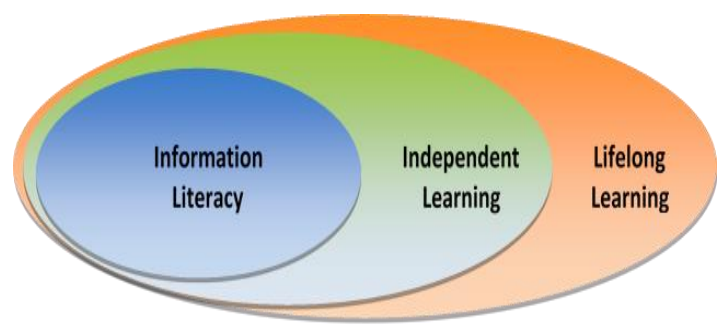

Figure 1. Relationship: IL, Independent Learning and Lifelong Learning Skills [8]

The CGA IL approach is based on the IL Competency Standards for Higher Education [4] definition that supports those seven competencies of the IL initiative. As all of these skills are critical, IL education in the Management Department at the USCGA must guarantee that those skills are mastered throughout four years so that every cadet who is ready to graduate becomes IL competent. These IL competencies are based on the ACRL [4] with specific expectations for freshman, sophomore, junior, and senior levels as presented in Figure 2. Introduction and continuous development of IL standards across the CGA curriculum have been accomplished at the CGA through library sessions, classroom lectures, activities, and trainings sessions related to research and writing assignments that have been carefully developed by Management Department and library faculty together to ensure that all students are developing and mastering IL competencies.

The Management Department at the USCGA uses a shared responsibility model (Figure 3) that allows informal assessment as evidence that students are learning the concepts needed to conduct research on an academic level. This formative assessment, with the student and professor involved, furnishes evidence of student learning, as its purpose is to improve the process of IL instruction.

To integrate IL across the Management major curriculum, the CGA faculty recognizes that it is critical to first identify and select required courses within freshman and sophomore year and then to continue moving into selecting courses that are provided at the junior and senior level.

The integration of IL over the time of study from one semester to another must be accomplished in assignment, coursework, or independent research projects. 


\begin{tabular}{|c|c|c|c|c|}
\hline IL Outcomes & $\begin{array}{l}\text { Distinguished } \\
\text { Master }\end{array}$ & $\begin{array}{c}\text { Proficient } \\
\text { Journeyman }\end{array}$ & $\begin{array}{l}\text { Progressing } \\
\text { Apprentice }\end{array}$ & $\begin{array}{l}\text { Baseline } \\
\text { Novice }\end{array}$ \\
\hline $\begin{array}{l}\text { Determine the Extent of } \\
\text { Information Needed }\end{array}$ & & & & \\
\hline $\begin{array}{l}\text { Access the Needed } \\
\text { Information }\end{array}$ & $\begin{array}{l}\mathbf{S} \\
\mathbf{E}\end{array}$ & $\begin{array}{l}J \\
\mathbf{U}\end{array}$ & $\begin{array}{l}0 \\
\mathbf{O} \\
\mathbf{P}\end{array}$ & $\begin{array}{l}\mathbf{F} \\
\mathbf{R}\end{array}$ \\
\hline $\begin{array}{l}\text { Evaluate Information } \\
\text { and Sources Critically }\end{array}$ & $\begin{array}{c}N \\
\text { I }\end{array}$ & $\begin{array}{c}N \\
\text { I }\end{array}$ & $\begin{array}{l}\mathrm{H} \\
\mathbf{O}\end{array}$ & $\begin{array}{l}\mathbf{E} \\
\mathbf{S}\end{array}$ \\
\hline $\begin{array}{l}\text { Use Information } \\
\text { Effectively to Accomplish a } \\
\text { Specific Purpose }\end{array}$ & $\begin{array}{l}\mathbf{O} \\
\mathbf{R}\end{array}$ & $\begin{array}{l}\mathbf{O} \\
\mathbf{R}\end{array}$ & $\begin{array}{l}\text { M } \\
\mathbf{O} \\
\mathbf{R}\end{array}$ & M \\
\hline $\begin{array}{l}\text { Obtain and Use Information } \\
\text { Ethically and Legally }\end{array}$ & & & E & $\mathbf{N}$ \\
\hline
\end{tabular}

Figure 2. The US Coast Guard Academy IL Rubric [30]

SHARED RESPONSIBILITY MODEL FOR DEVELOPING THE IL SKILLS

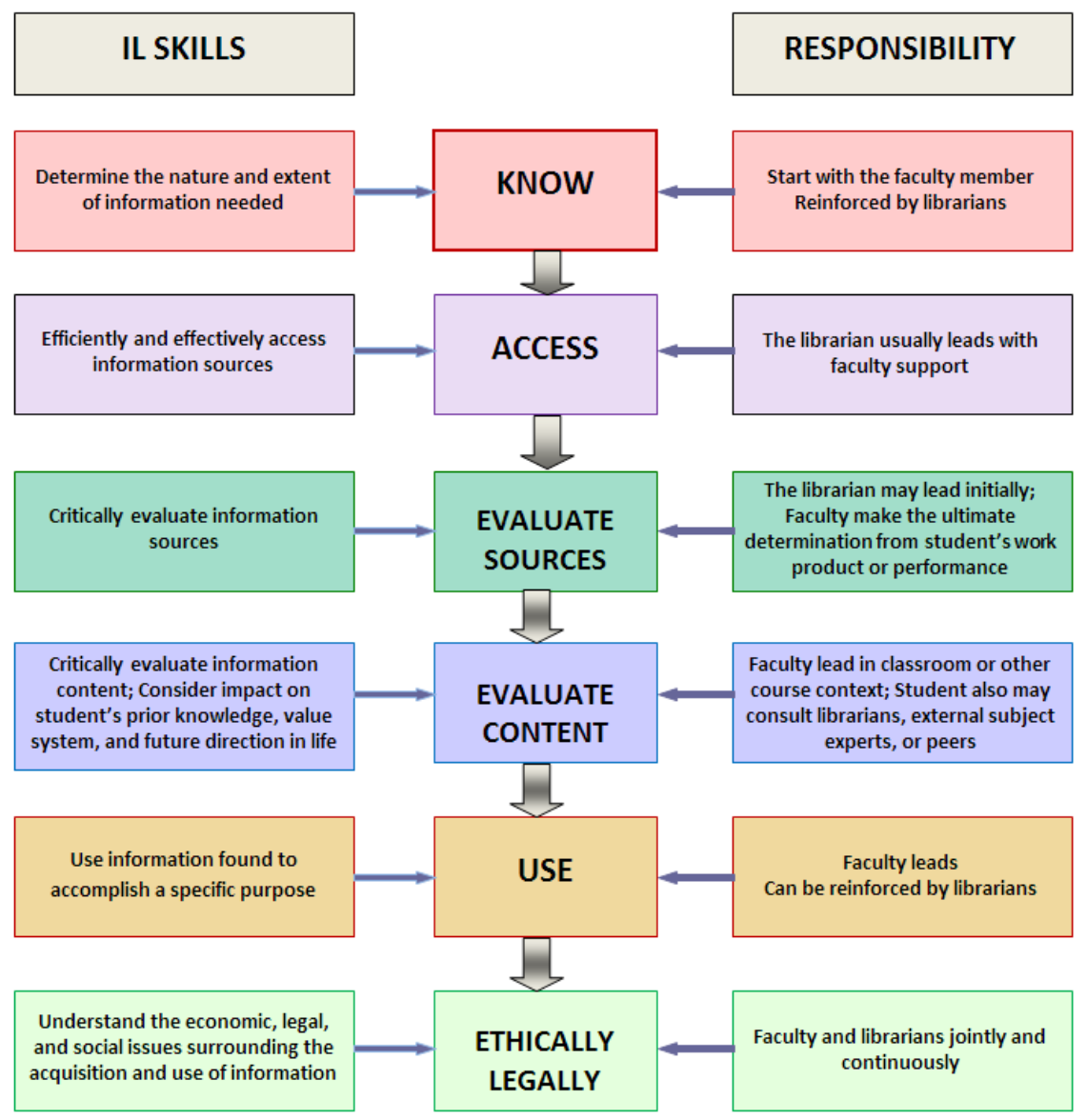

Figure 3. Shared Responsibility Model for Developing the IL Skills [4] 


\section{INFORMATION LITERACY PROCESS FOR STRUCTURING ASSIGNMENTS, PAPERS, AND RESEARCH PROJECTS}

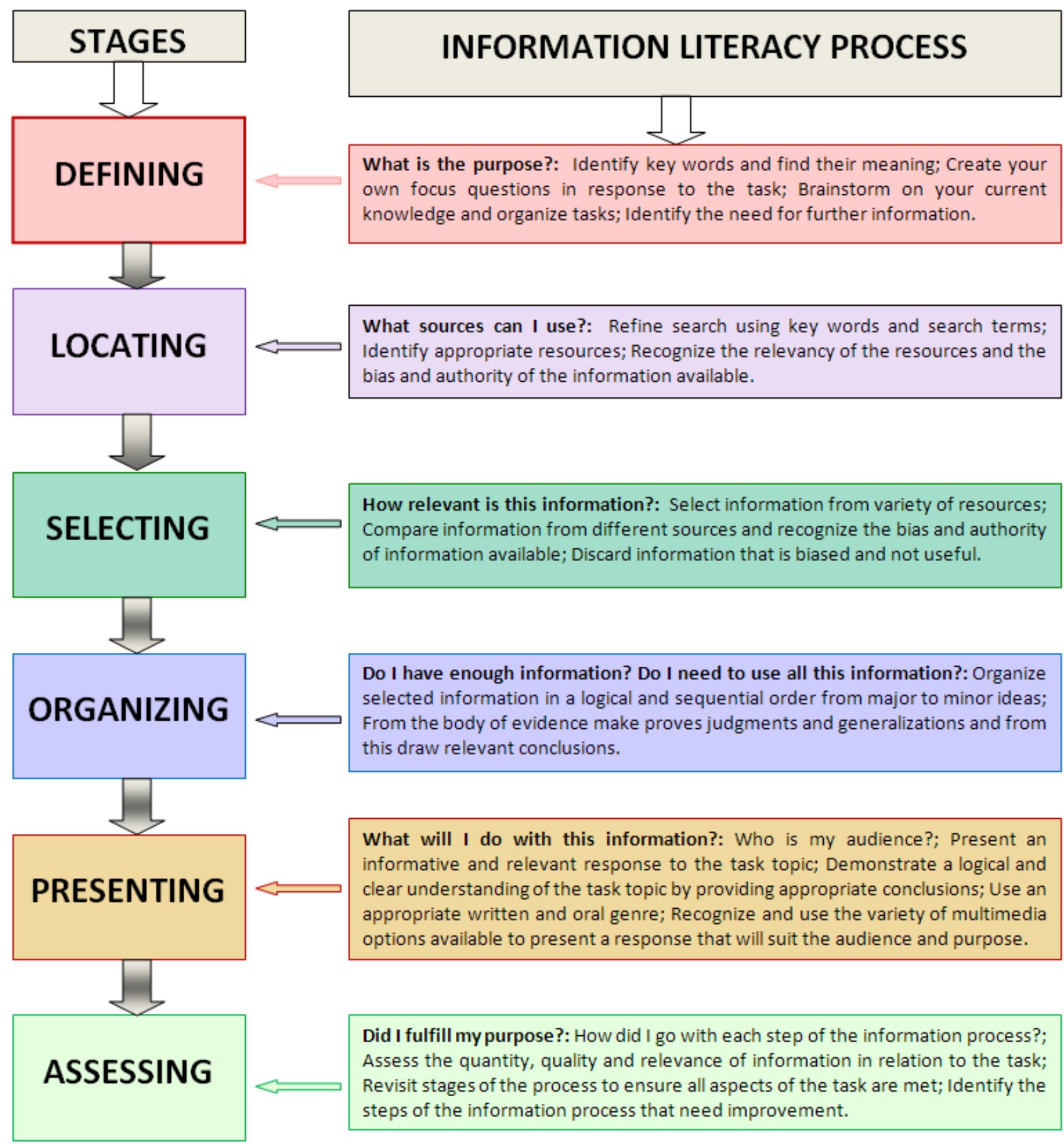

Figure 5. IL Process Description for Structuring Assignments, Papers, and Research Projects 
This approach enables students to continuously and successfully learn how to recognize when specific information is required and to develop an ability to find, evaluate, and apply information effectively as requested or expected in an assignment or research report. IL at the CGA has been integrated into the business coursework goals and objectives gradually over time so that cadets move from basic to more advanced and sophisticated methods of finding, collecting, assessing, and processing information to complete research tasks and problem-solving assignments and reports.

\subsection{Process for Developing IL Skills}

In the Management Department, the first step of the IL educational process has been offered by the library faculty who help students find information resources for their assignments. The CGA library faculty offers tutorials and discussion groups that enable students to perform active and experiential learning exercises that reinforce IL concepts that were taught during lecture. Following these exercises, students are required to complete short online practice assignments which focus on searching and finding resources and databases. After those introductory IL sessions, the librarians are always ready to assist regular academic faculty with their IL teaching. At this stage, the IL concepts are developed within economics and business subjects while students are required to find, select and apply specific information to solve business problems or analyze and answer economics questions. The research assignments, while conducted at a more advanced level, help cadets explore in detail a specific issue and learn how to select and collect appropriate information to conduct research and write reports within the specific course. Students become critical thinkers within the topics of their research papers, and they learn by applying their specific knowledge while developing a research assignment or class project. In their senior year, cadets are required to find, assess, and create new research information that they must apply into completing their assignments and undergraduate research thesis.

The Management Department members provide IL assignments within their own courses where they expect students to develop an ability to ask research questions and locate, evaluate, and apply information in a range of business and economics contexts. The CGA faculty also expects students to retrieve information using a variety of resources and then to demonstrate their ability to interpret and evaluate information via written report or oral presentations. The CGA Management Department's IL process consists of six key components with related tasks that are summarized in Figure 4. The six elements or steps of the IL process include: defining, locating, selecting, organizing, presenting, and assessing. At the senior level, all cadets are expected to be capable of finding and accessing information, applying it into their research processes, critically evaluating information, and properly documenting references and citations; the intent is that their senior projects will demonstrate these abilities.

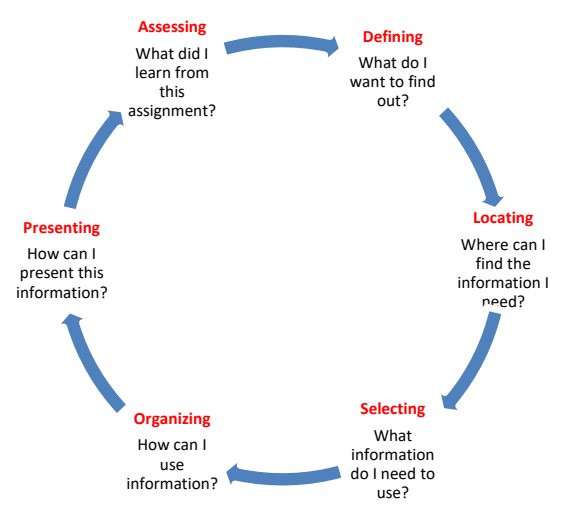

Figure 4. IL Process

Pedagogical approaches to teaching students to find, select, organize, and assess IL sources can be individualized to faculty pedagogical styles and can vary across the subjects or courses involved. The essentials for finding, selecting, organizing, and evaluating sources are addressed by the Management faculty during their lectures, library discussion meetings, and in-class writing workshops. For example, in introductory courses that are taken during the freshmen year, in-class and library-assisted workshops illustrate the differences between academic and non-academic sources of information. In those freshman courses cadets must produce a research assignment while utilizing traditional library catalogue together with electronic resources. At this freshman level, the research writing assignments can be challenging as freshman students are expected to learn the material and to find, examine, select, and use a range of academic and popular resources as they work on the English, history or economics assignments. When assignments are complete cadets must evaluate if the information they found and the resources they used successfully contributed to completing the assignments.

In more advanced courses at the junior or senior level, cadets are required to start understanding the multifaceted elements of information and gaining significant insights about the IL process. This process is accomplished through the cadet's own investigations and experiences of going through the IL process in writing assignments, reports, and research projects. 
However, these experiences can result from educational opportunities that go beyond lectures or library instruction but must require students to have hands-on exercises that require them to practice finding, selecting, assessing, organizing, and applying information into solving problems within specific real case examples. Homework assignments together with oral or visual presentations can be challenging when students are expected to engage in critical thinking process and analysis while conducting more advanced IL exercises. Commonly used by the Management faculty are short reports or papers that examine in specific IL sources that include journal and magazine articles or short assignments that require students to compare as well as to contrast the make-up and content of academic and popular IL sources. The CGA Management Department recognizes the challenge of today's research is not solely based on finding information but based on defining, locating, selecting, organizing, presenting and assessing the validity, importance, and relevance of information to the assigned research investigation. The Management faculty also understand that achieving competency in IL requires development of fully integrated IL strategy into the curriculum's content, structure, and sequence of coursework. Figure 4 presents a detailed IL process that has been adapted and used while structuring assignments, term papers or small research projects.

\section{Examples of Developing IL Skills}

The next section of this paper demonstrates how the IL process has been incorporated within several different projects and assignments across Management curriculum.

\subsection{Developing IL Skills in Macroeconomics Principles Course}

To teach IL effectively, the Principles of Macroeconomics course develops the pedagogical framework of problem solving in the freshman year. Successfully integrating the IL skills process was designed through group projects where students must share the responsibility for successfully completing their group projects and are required to go through and develop the IL process through defining, locating, selecting, and organizing the information that needs to be used to complete the assignment which is presented at the end of class. In this course, students reinforce learning basic macroeconomics concepts in addition to development of IL skills. This course demonstrates that teaching IL skills must combine learning the basic macroeconomics concepts with theories and models.
Example of the IL Principles of Macroeconomics Assignment is provided in Appendix A as Example 1.

\subsection{Developing IL Skills in Organizational Behavior and Leadership Course}

In a course Organizational Behavior and Leadership, taught at the sophomore level, students are expected to work on an IL assignment, called the Identity Assignment, where they are required to reflect on their experiences and analyze responses using Identity and Leadership theory. A copy of this IL assignment is provided in Appendix A: Example 2. Figure 6 represents the IL Process in an Organizational Behavior and Leadership Course.

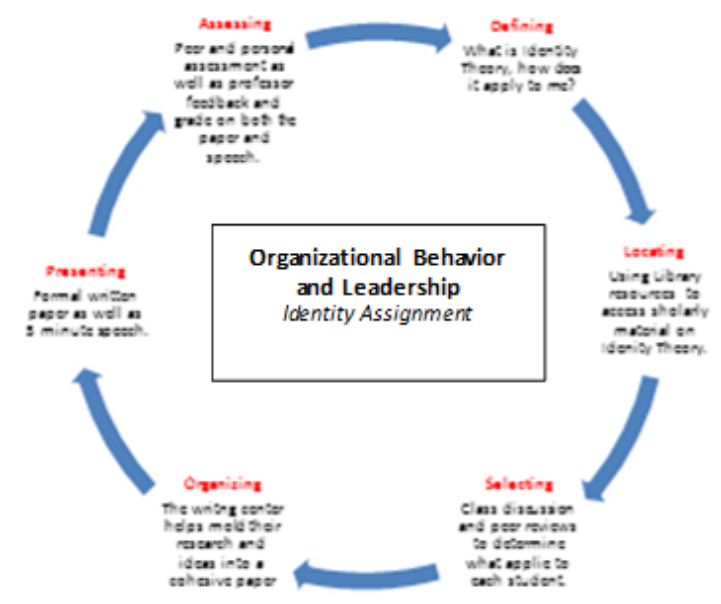

Figure 6. IL Process in the Organizational Behavior and Leadership Course

In the defining stage of the Identity Assignment, Organizational Behavior and Leadership students are instructed to reflect on their experiences and analyze them through current research to construct a validated personal Identity or Leadership theory which explains who they are and why. All students begin the locating stage at the library. Here library staff helps cadets validate their thesis and initiate research agendas. Once their agendas are set, cadets use library databases to select at least three "scholarly" or "academic" works on Identity or Leadership theory and submit an annotated bibliography with the full reference using APA citation style. Additional articles may be used but are not required to be "scholarly" or "academic".

Once the annotated bibliographies are assessed, students will begin the organizing phase with the goal of compiling their research and personal experiences into a completed first draft, which they will bring to the CGA Writing Center for a writer's workshop. During 
the workshop, the CGA Writing Center ensures all components of the assignment are met as students share their work with one another in a peer review as well. This begins the presenting phase, as students use feedback from the workshop to polish their final paper as well as work on their five minute speeches. The final assessment stage occurs when Management majors submit their papers for review and a grading by the instructor and present their findings to the class in a five minute speech. The student receives feedback from the instructor as well as their peers to ensure that they receive a holistic evaluation on their findings. Overall, this process ensures that IL is at the foundation of their work, and the quality of papers and speeches has increased over the past two semesters in which this has been in effect.

\subsection{Developing IL Skills in Introduction to Business Class}

Management majors in their sophomore year are required to take Introduction to Business. This course is an introduction into the Management major with the purpose of mastering six core business competencies that include: Business Ethics and Social Responsibility, Management, Operations, Human Resource Management, Marketing, Finance and Accounting. Students are also expected to develop self-directed learning that will enable them to effectively retain core business concepts. Each of the core business competencies becomes a full-semester course that Management majors are required to take after successfully passing Introduction to Business. In addition to development of students' business fundamentals, students are introduced to discipline specific IL skills. The primary assignment to assess business specific IL skills is a semester-long research project where students work on a selected company to analyze external factors, strategies, and performance outcomes. To prepare students for this IL project, the course begins with a three-lecture workshop on business-specific IL skills. In this workshop they determine the nature and extent of information needed, evaluate and use resources selected, and organize the results of their searches within a research log. Students must demonstrate knowledge of each of the IL standards that are found in Table 1. Following the workshop, students work individually to identify, locate, and synthesize relevant information for their required term paper assignment. The IL assignment for Introduction to Business is provided in Appendix 1 Example 3.

\subsection{Developing IL Skills in Management Information Systems Course}

Management Information Systems is a junior level course which explores the role of technology in organizations and society. The purpose of the course is to equip future managers with a solid understanding of information systems (IS), information technology (IT), and their application to running an organization. Topics covered in the course include Moore's Law, internet technology, social media, databases, and information security. The IL assignment in the Management Information Systems class is provided in Appendix 1 Example 4. This assignment provides students with an opportunity to analyze an organization's use of IT and/or IS in the context of the concepts taught within the course. Students will define key concepts as they relate to the organization which they have selected. Students will locate relevant information online in a variety of sources that pertains to their organization, IT/IS concepts, and the business functions that that IT/IS are supporting. They must be able to evaluate the accuracy and validity of the information they discover and select appropriate resources that provide high quality information. A course web page on the library's website serves as starting point for locating relevant, reliable information. Management majors will be required to organize the information to determine the relationships between the information from across all resources. The case study is to present a professional analysis of the organization and its successes and failures in its use of IT. Finally, students' analysis should synthesize information they have discovered through their research with topics covered in class in order to form their own assessment of the organization and its use of IT.

\subsection{Developing IL Skills in Project Management Consulting}

In the Project Management Consulting (PMC) course, the capstone course for the Management Department, senior students are assigned to work on business consulting projects. They work in small groups for an external client to produce consulting reports regarding specific business problems that they are expected to address for a selected client. The projects span a variety of topics including but not limited to: human capital management, marketing, finance, information systems, accounting, and acquisitions. Information Literacy Process in the Project Management Consulting is presented in Figure 6. 


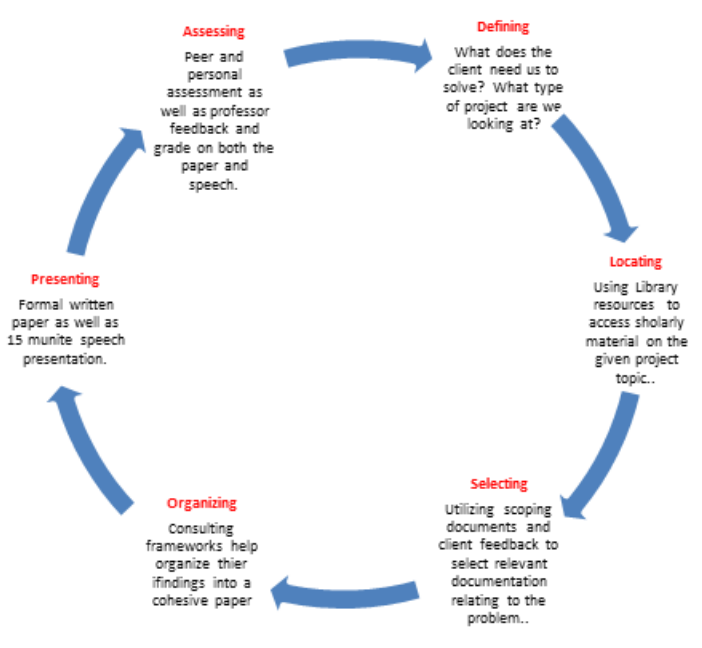

Figure 6. IL Process in the Project Management Consulting

The IL process begins with the students defining their project as they understand it when it is assigned. They conduct a literature review where they must locate credible sources that pertain to their overall project topic. Once this is complete, faculty provides feedback to the students on the quality of the literature review including the relevancy, credibility, and reliability of the data and sources presented. The information from the literature review is then used as they work with the client to properly scope their project considering client expectation/needs, team abilities, and schedule limitations. It should be noted that during discussions with the client, the groups implicitly receive feedback regarding their locating and selecting of data, which directly allows them to competently communicate with the client. Once the limitations and expectations for the group are clarified, they go back and select the appropriate, applicable documentation to work with and move forward. Then, the groups interpret and synthesize the information to produce specific recommendations for the client. Finally, the groups utilize consulting frameworks to organize the data and present in a logical format. Once the team completes their project recommendation, they are expected to present the project to clients, interested parties, and CGA faculty. Throughout the entire process and during the presentation phase, they are given assessments (from peers and faculty) regarding the quality, clarity and relevancy of their work. This completes the IL cycle for the course. The entire process uses multiple iterations of the IL cycle and ensures high quality PMC research projects from the student groups.

\section{Evidence Of Learning And Student Assessment}

An effective assessment process of students' learning must be conducted with a detailed analysis and observation throughout the entire learning process. The IL skills assessment of individual student requires collecting, analyzing, assessing, and reporting IL skills acquired by students in each individual course and it must be conducted through the entire IL learning process across selected and designated courses [21], [3]. This course-based assessment process provides an efficient and complete technique that is effective in improving and advancing IL competences among students. Dunn [15] argues that student-individual assessment must be used as it effectively reveals areas of IL skills that need more attention and work to make sure students are effectively developing and applying IL skills across different courses from their freshman to senior level.

Assessing cadet learning is a major focus of IL education at the CGA. Rubric assessment of IL is a valuable tool for both CGA librarians and faculty seeking to show evidence of cadet learning. Table 5 in Appendix B presents the Academy's instrument for assessment of IL skills. Across four years of the undergraduate program all Management majors are evaluated on IL skills within the following five competences: (1) Determine the Extent of Information Needed, (2) Access the Needed Information; (3) Evaluate Information and Sources Critically; (4) Use Information Effectively to Accomplish a Specific Purpose; and (5) Obtain and Use Information Ethically and Legally (Source: Informational Literacy Competency Standards for Higher Education [4]. For example, freshman cadets are expected to master IL skills at a Baseline/Novice level, sophomore students a Progressing/Apprentice level, junior students at a Proficient/Journeyman level, and senior students at a Distinguished/Master level.

The CGA is being held to an increasing level of responsibility for making sure that cadets are learning and that resources are used efficiently. The IL assessment initiative includes both direct and indirect means of assessments. In addition to indirect classroom assessment activities that are being conducted, the CGA library is planning to initiate a new direct and standardized assessment process across all majors. Some of the questions that the assessment instrument is expected to measure might answer following questions recommended by Dunn [15]: How do cadets approach and complete information tasks using computer and library resources?; How are strategies and resources cadets use related to the products of their work?; What pedagogical issues might emerge 
from an analysis of observed information-seeking strategies?; and What similarities and differences exist among faculty, librarians, and students in their conceptualization of information-seeking strategies? The goal of this instrument will be to maintain the quality of IL educational process at the CGA overtime.

\section{Conclusion}

As technology continues to transform learning, the development of IL skills is vital. As an infinite amount of information is available, students need to develop a solid understanding of IL skills. Today, IL provides essential skills that students must acquire and use to obtain the best information for their problem solving, research projects or assignments, and finally, decision making. The importance of incorporating IL instruction within each course of any academic program serves as a complement to library IL instruction and it assists with meeting the academic standards for IL proficiency.

The CGA Management Department's IL program has been planned with an intention to facilitate learning and to master IL knowledge so that cadets become in charge of their own learning and acquiring the best information for their lifelong learning and decision making. The attainment of the IL educational outcomes is based on Association of College and Research Libraries outcomes. Through specifically designed IL assignments, Management Department faculty established the framework for learning, inspired students to explore the indefinite area of information, provided assistance on how to meet information requests, and monitored cadets' progress throughout four years of instruction.

The IL process has been developed where six stages have been used to enable cadets to master IL skills. Those stages include: defining, locating, selecting, organizing, presenting, and assessing. Opportunities for learning IL skills must be initiated right away during freshman year and then reinforced throughout the curriculum up to a senior level. The CGA librarians are expected to assist the Management Department faculty with the evaluation and selection of intellectual and information materials and resources based on coursework needs, maintain a collection of numerous academic sources, and provide instruction to cadets who seek information. However, students' IL competencies must be developed through the collaboration of library instruction and Management faculty. This strategy benefits the cadets by allowing cadets to move from basic (Baseline/Novice) IL skills to IL fluency (Distinguished/Master) as this initiative has been implemented throughout four years of undergraduate study and became a major component of cadets' IL experience. Becoming information fluent makes cadets successful in their studies and prepares them for their lifelong learning as they learn how to obtain, manage, and use required information to their best advantage.

In conclusion, it can be said that research assignments and projects with the use of assessment techniques must be applied so that library and faculty IL instruction can be improved within each course where IL skills are being developed and practiced. The development and evaluation process of IL skills must be used over four years of undergraduate study and become a required strategy, not only across the core curriculum but specifically within courses in the Management major to assist cadets in developing into confident, self-directed, and independent life-long learners. In the present national climate of accountability, librarian instructors and CGA faculty face an increasing responsibility to demonstrate that value with evidence. IL strategy and its assessment process must be fully integrated into four-year coursework and built upon the educational mission of the institution in order to provide the most effective results of IL proficiency in cadets' development, learning, and mastering of IL skills.

\section{References}

[1] American Library Association - ALA. (1989). Presidential Committee on Information Literacy: Final Report (Washington, DC: ALA, 1989); ALA, Association of College and Research Libraries (ACRL), Information Literacy Competency Standards for Higher Education (Chicago: American Library Association).

[2] American Library Association - ALA. (2000) ACRL. http://www.ala.org/acrl/standards/informationliteracycompe tency.

[3] American Association of School Librarians - AASL. (1998). Information power: building partnerships for learning. Chicago: American Library Association.

[4] Association of College and Research Libraries - ACRL. (2000). Information Literacy competency standards for higher education. (Chicago: American Library Association, 2000).

[5] Association of College and Research Libraries - ACRL. (1998). Infor $\neg$ mation Literacy competency standards for higher education; American Association of School Librarians, Information Literacy Standards for Student Learning, American Library Association, http://www.Ala. org/ala/aasl/aaslproftools/informationpower/InformationLite racyStandards_final.pdf.

[6] Biggs, J., \& Tang, C. (2011). Teaching for quality learning at university (4th ed.). Maidenhead, NY: McGrawHill/Society for Research into Higher Education. Open University Press. 
[7] Bruce, C. (2004). Information literacy as a catalyst for educational change: A background paper. In P. A. Danaher (Ed.). Lifelong learning: Whose responsibility and what is your contribution? The 3rd International Lifelong Learning Conference, 13-16 June 2004, Yeppoon, Queensland.

[8] Bundy, A. (ed.) (2004) Australian and New Zealand Information Literacy Framework principles, standards and practice, 2nd ed. Adelaid: Australian and New Zealand Institute Information Literacy.

[9] Carbery, A., \& Hegarty, N. (2011). Introducing problembased learning into one-shot information literacy instruction at Waterford Institute of Technology Libraries. SCONUL Focus, 53, 30-33.

[10] Carder, L., Willingham, P., \& Bibb, D. (2001). Casebased, problem-based learning: Information literacy for the real world. Research Strategies, 18(3), 181-190.

[11] Cochrane, C. (2006). Embedding Information Literacy in an undergraduate management degree: lecturers' and students' perspectives. Education for Information, 24(2-3), 97-123.

[12] Collis, B. \& Van der Wende, M. (2002). Models of technology and change in higher education: an international comparative survey on the current and future use of ICT in Higher Education. Report, December 2002. Twente: Center for Higher Education Policy Studies (CHEPS).

[13] Doyle, C. (1992). Outcome measure for Information Literacy within the national educational goals of 1990. Final Report to the National Forum on Information Literacy. Flagstaff: AZ, NFIL.

[14] Drueke, J. (1992). Active learning in the university library instruction classroom. Research Strategies 10, 78. [15] Dunn, K. (2002). Assessing information literacy skills in the California State University: A progress report. Journal of Academic Librarianship, 28(1-2), 26-35.

[16] Farkas, M. (2012). Participatory technologies, pedagogy 2.0 and Information Literacy. Library Hi Tech, 30(1), 82-94.

[17] Foster, N.F., \& Gibbons, S. (2007). Studying students: the undergraduate research project at the University of Rochester. Chicago: Assn of College and Research Libraries.

[18] Ghaith, G. (2010). An exploratory study of the achievement of the twenty-first century skills in higher education. Education and Training, 52(6/7), 489-98.

[19] Hepworth, M. (2000). Approaches to providing information literacy training in higher education: challenges for librarians. The New Review of Academic Librarianship, 21-34.

[20] Horton, F. W. (2008). Understanding Information Literacy: A primer. The United Nation Educational, Scientific and Cultural Organization, Communication and Information Sector, Paris, France: UNESCO.

[21] Huba, M. E., \& Freed, J. E. (2000). Learner-centered assessment on college campuses: Shifting the focus from teaching to learning. Boston, MA: Allyn and Bacon.

[22] Kuhlthau, C. C. (1987). Information skills for an information society: a review of research. Syracuse, NY: ERIC Clearinghouse on Information Resources. ED 297740.

[23] Kuhlthau, C.C. (2013). Rethinking the 2000 ACRL standards: some things to consider. Communications in Information Literacy, 7(3), 92-97.

[24] Lorenzen, M. (2001). Active learning and library instruction. Illinois Libraries, 83(2), 19-24.

[25] Lubans, J. Jr (1978). Progress in educating the library user. New York, NY: Bowker.

[26] Moll, M. (2009). Information Literacy in the new curriculum. South African Journal of Libraries and Information Science. 75(1), 40-45.

[27] Niedbala, M. A., \& Fogleman, J. (2010). Taking library 2.0 to the next level: using a course Wiki for teaching Information Literacy to honors students. Journal of Library Administration. 50 (7-8), 867-882.

[28] Pastine, M., \& Wilson, L. (1992). Curriculum reform: The role of academic libraries. In B. Baker and M. E. Litzinger (Eds.), The revolving educational mission of the library (pp. 90-108). Chicago: Association of College and Research Libraries.

[29] Ratteray, O. M. (1985). Expanding roles for summarized information. Written Communication: A Quarterly Journal of Research, Theory, and Application, 2 (4), 457-472.

[30] Ratteray, O. M. (2002). Information literacy in selfstudy and accreditation. Journal of Academic Librarianship, 28(6): 368 .

[31] Sefton-Green, J, Nixon, H. \& Erstad, O. (2009). Reviewing approaches and perspectives on digital literacy. Pedagogies: an International Journal, 4(3), 107-25.

[32] Wenger, K. (2014). Problem-Based learning and Information Literacy: a natural partnership. Pennsylvania Libraries: Research and Practice, 2(2), 142-154. 


\title{
APPENDIX A
}

\section{EXAMPLE 1: Principles of Macroeconomics (FRESHMAN LEVEL)}

\author{
Principles of Macroeconomics/Information Literacy Assignment
}

Name

Section

The purpose of this assignment is to allow you to explore basic Macroeconomics concepts beyond what we discussed in class as well as to allow you to understand them better and to take informed positions on them. This project is also expected to concentrate on improving your information literacy competency. You will need to frame a topic, choose workable databases, and sources concerning the topic, and briefly cite and evaluate these resources you chose to use. In order to complete these assignments please work the following tasks.

Please seek assistance from the library staff whenever you have questions about the databases or the research process. The topic selected and the question that you seek to answer may not be represented in each type of source available in a library catalog or online. It's not likely that you'll find a whole magazine article, a whole newspaper article, or a whole book, on that exact topic. Please be flexible and leam to examine each resource for any relevant information it may contain about your topic and the question you seek to answer. If you can"t find information on a topic please see your instructor or a librarian. When you search, try different terms, and keep track of the terms that work well. You will notice that change in a term typed during your library will provide different results.

Select one of the following topics and then answer the following questions that are listed below.

1. Explain how the concepts of scarcity, incentives, opportunity cost, and marginal analysis affect economic decision making.

2. Analyze the role of supply, demand, and prices in a market economy and the necessary conditions for a market economy to function well and then describe and critique the role of government in a market economy.

3. Explain the importance of long run economic growth, and the factors that contribute to growth.

4. Explain the concept of comparative advantage, the gains from international trade, the role of exchange rates, and the effects of globalization.

(DEFINING) What do I want to find?

- Choose a topic of your assignment proposed by your instructor; What issue are you examining what questions are you trying to answer? Determine possible key words or terms to begin database searching. Limit your search to get better results

(LOCATING) Where can I find the information I need?

- Control vocabulary and keyword searches; Search engine directories and then Create a documentation file of research activities and their outcomes; and Access suggested databases, listing key words terms used in each one

(SELECTING) Whatinformation do I need to use?

- Evaluate each database and record potentially useful sources of information and items for further evaluation

- From the materials identified above, select (and justify your choices)

o three books or selections/chapters from books three articles from scholarly journals/three articles from general audience (popular) magazines or newspapers three sources from an Internet search engine (www.Google.com),

- Select those sources that provide the best and most reliable information and evaluate selected information for its accuracy, relevance, and content

- Read the text and selects main ideas and justify your choice and selection process

(ORGANIZING) How can I use information?

- Complete your database search, list all selected resources, and evaluate all information selected

- Recognize interrelationships among concepts and combine them into primary statements with supporting evidence

- Organize your resources based on relevance and importance of your search and cite all sources that you selected and organized in the reference style attached to these guidelines

(PRESENTING) How can I present this information?

- Present information ethically and legally; Organize facts by topically/chronologically/value contribution; Identify each article's significance and potential contribution to the assignment; Choose a communication format that best supports your argument and select the intended audience; and Communicates clearly and with a style that supports the purposes of the intended audience

(ASSESSING) What did I learn from this assignment?

- Determine whether information satisfies the research; Draw conclusions based upon information gathered; Determine probable accuracy by questioning the source of the data, the limitations of the information gathering tools or strategies, and the reasonableness of the conclusions; Integrate new information with previous information or knowledge; Select information that provides evidence for the topic

Source: Management Department, the U.S. Coast Guard Academy. 


\title{
EXAMPLE 2: Organizational Behavior and Leadership (SOPHOMORE LEVEL)
}

\section{Class of 1959 Writing and Speaking Assignment}

\section{Name}

\section{Section}

\begin{abstract}
:
As you reflect on your identity, it is imperative to ask the question what makes you, you?

Analyzing this question through the lenses of different identity and leadership theories, you must determine the influences and processes that shaped you.

Research Question: Who are you, who do you want to be, and how will you get there?

Paper Criteria (75\%):

Answer the above question using personal reflection insight from classoom theorv, and a comprehensive liter ature review. This paper is not a story about your life, but a critical analysis of your past, current, and future identity via the different models from this course and your literature review. Your literature review must include at least three academic sources that prove your thesis.

Example A concrete experience shaped your identity; this is validated by Kolb's Experiential Learning Model.
\end{abstract}

Structure:

\section{Who wereyou

Format:

1.) 5 pages, double spaced, 12-point Times New Roman, 1" margins, MLA citations

a. Title page with name, cadet code, title, and instructor's name.

b. Running headers with title (not name) and page number.

c. Works Cited (in addition to five pages)

Speech Criteria (25\%):

1.) Five minute speech, no visual aids, and note cards discouraged

a. Formal introduction, including your thesis and main points

b. Structured speech with innovative style (not a speech on your life story)

c. Confident and poised delivery

Contest:

1.) LCDR (ret.) John Hewitt and his wife Ema established this annual competition to stimulate and enrich the development of written and oral communication for the Corps of Cadets.

a. Cash prizes will be awarded to first, second, and third place

Source: Management Department, the U.S. Coast Guard Academy. 


\title{
EXAMPLE 3: Introduction to Business (SOPHOMORE LEVEL)
}

\author{
Introduction to Business/Information Literacy Assignment
}

Name

Section

The purpose of this term paper assignment is to develop self-directed leaming behaviors to retain core business knowledge. Each of the six business competencies are full semester courses that a Management major will take in their academic plan of study following Introduction to Business. Additionally, this assignment exposes students to basic business fundamentals and discipline specific information literacy skills. Students work individually over the semester to utilize information literacy and research skills to identify, locate, and synthesize relevant information for their tem paper assignment. Students conduct research to complete an information literacy assignment in the form of an informative report on a specific company which analyzes external industry influences, best practices in any industry, and the company's overall performance.

Complete the research assignment by addressing each of the following topics:

- Explain how the company you are researching is/ performing with respect to Business Ethics and Social Responsibility, Management, Operations, Human Resource Management, Marketing, Finance and Accounting

- Analyze best practices in any industry for Business Ethics and Social Responsibility, Management, Operations, Human Resource Management, Marketing, Finance and Accounting

- Analyze competitor performance within the same industry with respect to Business Ethics and Social Responsibility, Management, Operations, Human Resource Management, Marketing, Finance and Accounting

- Analyze extemal influences that affect Business Ethics and Social Responsibility, Management, Operations, Human Resource Management, Marketing, Finance and Accounting

(DEFINING) What do I want to find?

- Choose a publically traded company proposed by your instructor

- What issue are you examining/what questions are you trying to answer?

- Determine possible key words or terms to begin database searching; Limit your search to get better results

(LOCATING) Where can I find the information I need?

- Control vocabulary and keyword searches

- Find information within the 5 information types (background, current events, data/statistics, analysis/opinion, peer-reviewed scholarly research)

- Library Guide (libguide for business research)

- Search engine directories; Create a research log of research activities and their outcomes

- Access suggested databases, listing key words/terms used in each one

(SELECTING) What information do I need to use?

- Evaluate each database and record potentially useful sources of information and items for further evaluation

- Use the CRAAP (currency, relevancy, authority, accuracy, purpose) Test to select appropriate sources to build analysis of the paper; Summarize the text and select main ideas to justify your choice and selection process

(ORGANIZING) How can I use information?

- Complete your database search, list all selected resources, and evaluate all information selected using a research log

- Recognize interrelationships among business concepts and synthesize them into statements with supporting evidence

- Organize your resources based on relevance and importance of your search and cite all sources that you selected and organized in the reference style attached to these guidelines

(PRESENTING) How can I present this information?

- Present all information ethically and legally; Organize facts by topically/chronologically/value/contribution

- Identify each article's significance and potential contribution to the assignment

- Choose a communication format that best supports your argument and select the intended audience

- Communicates clearly and with a style that supports the purposes of the intended audience

(ASSESSING) What did I learn from this assignment?

- Draw conclusions based upon information gathered on the performance of the company and if there are opportunities for improvement to remain competitive within the industry

- Determine how critical thinking and questioning the source of the data enhanced the research process

- Integrate new information with previous information or knowledge

Source: Management Department, the U.S. Coast Guard Academy. 


\title{
EXAMPLE 4: Management Information Systems (JUNIOR LEVEL)
}

\author{
Management Information Systems Case Study Assignment
}

Name

Section|

The purpose of this assignment is for you to apply what you have leamed in this course in order to analyze an organization's use of information technology (IT) and/or information systems (IS). This assignment will also serve to exercise your information literacy skills as you search for reliable information sources, synthesize that information in your analysis, and properly reference the re sources used. Your analysis should incorporate concepts and topics covered in the course as they relate to the organization you have selected. In this case study, you may highlight successes as well as failures of your subject organization. You may choose a business, govemment agency, or non-profit organization as the subject of your case study. All proposed organizations must be approved by the instructor.

As a starting point for your research, you may visit the course page on the library's website at http://libguides.uscga.edu/mis8331. The library staff can provide you with further assistance in researching your selected organization and related information.

In examining the organization of your choosing, you should analyze how it uses information technology. The following is a list of the type of questions that your case study should address:

- What IT and IS does the organization use?

- How does the organization leverage IT and information systems to its advantage?

- Is the organization's IT based success sustainable in the future?

- Has the organization been unsuccessful or experienced setbacks due to a poor implementation of IT or a lack of clear IT strategy?

- If the organization is or has been unsuccessful due to failed IT, how did or will they recover?

- Does the organization's use of IT differentiate itself from competitors or similar organizations?

(DEFINING) What do I want to find?

- Choose an organization as described above.

- In what way does the organization use information technology or information systems?

- Relate the organization's use of IT and IS to concepts covered in the course.

- Identify the keywords that are related to the organization, relevant IT/IS concepts, or the business functions that IT/IS provides to the organization.

(LOCATING) Where can I find the information I need?

- MIS course page (http://libguides.uscga.edu/mis8331)

- Research databases; Technology sections of periodicals and newspapers (NY Times, Businessweek, etc.); Course text

(SELECTING) What information do I need to use?

- Evaluate the information and sources you find to select accurate, reliable information from credible sources.

- Select a minimum of five online resources (not including the text) consisting of at least: One magazine article; One newspaper article; The subject organization's website

(ORGANIZING) How can I use information?

- List all sources selected above and the concepts covered by each source.

- Identify how the information is related, instances where sources support or contradict other sources.

- Arrange your resources based the relevance to your case study and cite all sources according to APA format.

(PRESENTING) How can I present this information?

- Arrange your information so that it presents a logical analysis of the organization's use of IT/IS.

- Write to an audience that has a fundamental understanding of IT concepts, but may not necessarily be familiar with your selected organization.

- Your case study should utilize a professional tone to present your analysis.

(ASSESSING) What did I learn from this assignment?

- Ensure that your research has produced an adequate amount of quality information that meets the requirements of sources as described above.

- Review the information you have discovered to ensure you provides support in answering the questions and issues listed above.

- Integrate the information from your research with the concepts you have leamed in class.

- From the information you have researched, develop a conclusion regarding the successes or failures of the organizations use of IT/IS.

Source: Management Department, the U.S. Coast Guard Academy. 


\section{APPENDIX B.}

\section{THE PMC (SENIOR LEVEL - ASSESSMENT LEVEL)}

\begin{tabular}{|c|c|c|c|c|}
\hline IL Outcomes & Distinguished/Master & Proficient//Journeyman & Progressing/Apprentice & Baseline/Novice \\
\hline $\begin{array}{l}\text { Evaluate Information } \\
\text { and Sources critically }\end{array}$ & $\begin{array}{l}\text { - Chooses a variety of high } \\
\text { quality sources appropriate to } \\
\text { the scope and discipline of the } \\
\text { research questions or theses. } \\
\text { - Critically and effectively } \\
\text { evaluates all information sources } \\
\text { for currency/timeliness; relevance } \\
\text { to research questions/theses; } \\
\text { authority/scholarly value, } \\
\text { accuracy/quality, and } \\
\text { purpose/bias. }\end{array}$ & $\begin{array}{l}\text { - Chooses a variety of } \\
\text { information resources that are } \\
\text { relevant to research questions or } \\
\text { theses. } \\
\text { - Consistently evaluates all } \\
\text { information sources for } \\
\text { currency/timeliness; relevance to } \\
\text { research questions/theses; } \\
\text { authority/scholarly value, } \\
\text { accuracy/quality, and } \\
\text { purpose/bias. }\end{array}$ & $\begin{array}{l}\text { - Chooses a variety of } \\
\text { information resources with } \\
\text { some relevance to research } \\
\text { questions or theses. } \\
\text { - Evaluates information sources } \\
\text { using some of the following } \\
\text { criteria: currency/timeliness; } \\
\text { relevance to research } \\
\text { questions/theses; } \\
\text { authority/scholarly value, } \\
\text { accuracy/quality, and } \\
\text { purpose/bias. }\end{array}$ & $\begin{array}{l}\text { - Selects just a few information } \\
\text { sources with limited relevance to } \\
\text { research questions or theses. } \\
\text { - Does not evaluate information } \\
\text { sources for currency/timeliness; } \\
\text { relevance to research } \\
\text { questions/theses; } \\
\text { authority/scholarly value, } \\
\text { accuracy/quality, and purpose/bias. }\end{array}$ \\
\hline $\begin{array}{l}\text { Use Information } \\
\text { Effectively to } \\
\text { Accomplish a } \\
\text { Specific Purpose }\end{array}$ & $\begin{array}{l}\text { - Communicates, organizes, and } \\
\text { synthesizes information from } \\
\text { sources to fully achieve a specific } \\
\text { purpose, with clarity and depth. } \\
\text { - Construction of new ideas } \\
\text { relates to the context of the } \\
\text { community of practice. }\end{array}$ & $\begin{array}{l}\text { - Communicates, organizes, and } \\
\text { synthesizes information from } \\
\text { sources. Intended purpose is } \\
\text { achieved. } \\
\text { - construction of new ideas } \\
\text { relates to the context of the } \\
\text { major. }\end{array}$ & $\begin{array}{l}\text { - Communicates and organizes } \\
\text { information from sources. The } \\
\text { information is not yet } \\
\text { synthesized, so the intended } \\
\text { purpose is not fully achieved. } \\
\text { - Construction of new ideas } \\
\text { relates to the context of the } \\
\text { course material. }\end{array}$ & $\begin{array}{l}\text { - Communicates information from } \\
\text { sources. The information is } \\
\text { fragmented and/or used } \\
\text { inappropriately (misquoted, taken } \\
\text { out of context, or incorrectly } \\
\text { paraphrased, etc.) so the intended } \\
\text { purpose is not achieved. } \\
\text { - construction of new ideas is } \\
\text { limited to the context of the } \\
\text { assignment. }\end{array}$ \\
\hline IL Outcomes & Distinguished/Master & Proficient/Journeyman & Progressing/Apprentice & Baseline/Novice \\
\hline $\begin{array}{c}\text { Determine the Extent } \\
\text { of Information } \\
\text { Needed }\end{array}$ & $\begin{array}{l}\text { Effectively defines the scope of } \\
\text { the research questions or thesis } \\
\text { statements and revises as needed. } \\
\text { - Identifies all key concepts. } \\
\text { - seeks out new information or } \\
\text { alternative perspectives and } \\
\text { successfully adjusts needs } \\
\text { accordingly. }\end{array}$ & $\begin{array}{l}\text { - Defines the scope of the } \\
\text { research questions or thesis } \\
\text { statements completely. } \\
\text { - Identifies most key concepts. } \\
\text { - Receptive to new information or } \\
\text { alternative perspectives and } \\
\text { adjusts needs accordingly. }\end{array}$ & $\begin{array}{l}\text { - Defines the scope of the } \\
\text { research questions or thesis } \\
\text { statements incompletely (parts } \\
\text { are missing, remains too broad or } \\
\text { too narrow, etc.) } \\
\text { - Identifies some key concepts. } \\
\text { - Recognizes the presence of new } \\
\text { information or alternative } \\
\text { perspectives but does not always } \\
\text { adjust needs. }\end{array}$ & $\begin{array}{l}\text { - Has difficulty defining the scope } \\
\text { of the research questions or thesis } \\
\text { statements. } \\
\text { - Unable to identify key } \\
\text { concepts. } \\
\text { - Does not seek new } \\
\text { information or alternative } \\
\text { perspectives. }\end{array}$ \\
\hline IL Outcomes & Distinguished/Master & Proficient//Journeyman & Progressing/Apprentice & Baseline/Novice \\
\hline $\begin{array}{c}\text { Obtain and Use } \\
\text { Information Ethically } \\
\text { and Legally }\end{array}$ & $\begin{array}{l}\text { - Very good/full understanding of } \\
\text { the ethical guidelines and legal } \\
\text { restrictions on obtaining and } \\
\text { using information in all formats. } \\
\text { - consistently distinguishes } \\
\text { between common knowledge, } \\
\text { original ideas, and ideas requiring } \\
\text { attribution. } \\
\text { - Consistently knows when to } \\
\text { quote, paraphrase, or summarize } \\
\text { the ideas of others and always } \\
\text { includes all necessary citations in } \\
\text { the proper format. } \\
\text { - Aware of multiple styles of } \\
\text { citation and knows which style is } \\
\text { appropriate for a given task. }\end{array}$ & $\begin{array}{l}\text { - Good understanding of the } \\
\text { ethical guidelines and legal } \\
\text { restrictions on obtaining and using } \\
\text { information in all formats. } \\
\text { - Able to distinguish between } \\
\text { common knowledge, original } \\
\text { ideas, and ideas requiring } \\
\text { attribution. } \\
\text { - Knows when to quote, } \\
\text { paraphrase, or summarize the } \\
\text { ideas of others and includes } \\
\text { properly formatted citations. } \\
\text { - Aware of more than one style of } \\
\text { citation and knows which style is } \\
\text { appropriate for a given task. }\end{array}$ & $\begin{array}{l}\text { - Demonstrates some } \\
\text { understanding of the ethical } \\
\text { guidelines and legal restrictions on } \\
\text { obtaining and using information in } \\
\text { all formats. } \\
\text { - Has some ability distinguishing } \\
\text { between common knowledge, } \\
\text { original ideas, and ideas requiring } \\
\text { attribution. } \\
\text { - some yoderstandiag, of when te, } \\
\text { gupterbacapbcase, or summarize } \\
\text { the ideas of others and includes } \\
\text { some properly formatted } \\
\text { citations. } \\
\text { - Aware of more than one style of } \\
\text { citation but does not know when } \\
\text { to use them. }\end{array}$ & $\begin{array}{l}\text { - Demonstrates a lack of } \\
\text { understanding of the ethical } \\
\text { guidelines and legal restrictions on } \\
\text { obtaining and using information in } \\
\text { all formats. } \\
\text { - Has difficulty distinguishing } \\
\text { between common knowledge, } \\
\text { original ideas, and ideas requiring } \\
\text { attribution. } \\
\text { - Incorrectly or inappropriately } \\
\text { guptes, paraphrases or summarizes } \\
\text { the ideas of others and omits or } \\
\text { incorrectly formats citations. } \\
\text { - Aware of only one style of } \\
\text { citation. }\end{array}$ \\
\hline
\end{tabular}

Source: The US Coast Guard Academy Library 